\title{
DEPORTATIONS OF KURTAŠ WORKERS IN THE ACHAEMENID EMPIRE ACCORDING TO CLASSICAL LITERARY TRADITION
}

\begin{abstract}
This paper discusses the mass deportations of kurtaš workers, as represented in ancient literary tradition. According to Ctesias, these people were war captives settled in different areas of the Achaemenid realm after their compulsory migration to the Empire. The body of workers comprised men, women and their children. The data from the ancient literary tradition is compared to the data in the Persepolis Fortification Tablets, as well as the Persepolis Treasury tablets. These archives commemorate kurtaš workers from South-Western Persia who worked in the Royal economy, being people from different parts of Empire, as well as beyond its borders. The literary tradition brings evidence on the practice of deportations during the reigns of other Great kings besides Darius the Great (in the PFT) and Xerxes and Artaxerxes I (in the PTT). Greek authors do not apppear to have a particular insight on this Achaemenid practice, therefore speaking of 'douloi' (slaves) on the basis of their own cultural and linguistic tradition. However, they also add new pieces in the puzzle concerning the mass deportations of workers in the Achaemenid Empire.
\end{abstract}

In this paper I examine the data on mass deportations of kurtaš workers in the Achaemenid Empire, presented in the classical ancient literary tradition. ${ }^{1}$ Ctesias of Cnidus, for example, testified repeatedly about hostages during military conflicts, who were resettled within the confines of the Achaemenid Empire. After their deportation, the hostages were resettled in different parts of the empire. The hostages were men, women and their children. That "profile" of the hostages - kurtaš workers - corresponds well to the workers attested in the royal estates in Persis and Elam, documented in the Persepolis fortification tablets. Therefore, the data from the ancient literary tradition will be compared with the Persian documents both from the Persepolis fortification and from the treasury. ${ }^{2}$ These archives contain evidence of kurtaš workers

${ }^{1}$ On the mass migrations and deportations in the Mesopotamian and Persian worlds, see: Potts, 2013b: 1-6; Shahbazi et al., 1994: 297-299.

2 Most of the evidence has been collected already by Hirsch, 1992: 230-239, but without detailed analysis. I add to his list some more recently noticed sources and 
who work on the royal estates in South-western Iran, as well as on the royal constructions in the Persian capitals. ${ }^{3}$ They were involved in the royal economy, being migrants from different parts of the empire and even from beyond its boundaries. It is curious to note that a number of such migrations by the Persian administration are found in the ancient literary tradition, beyond the reign of Darius I to which the archive of the fortification of Persepolis and the tablets from the treasure house are dated - both to his time and to the reigns of Xerxes and Artaxerxes I. The Greeks did not have a clear idea about the social status of these resettled people and referred most generally to them as douloi (slaves), in the cases when they mentioned similar migration events, thus comparing the foreign realities with their own cultural and linguistic environment. On their part, they contributed with different nuances to that Persian practice, which is known to us in its final materialised variant from the Persepolis archives. The (predominantly) Greek evidence completes the picture of the mass deportations carried out by the Persian authorities. ${ }^{4}$

More than twenty reports of mass deportations are known from ancient Greek (and Roman) historiography. These data are connected with the activities of the Persians in the Mediterranean. There exist opinions that place those mass migrations entirely in a Greek cultural environment, especially in Herodotus' Histories. ${ }^{5}$ The Greek phenomenon referred to as metoikesis (organised migration of a polis) cannot be linked with the mass migration of communities attested in $\mathrm{He}-$ rodotus and other Greek authors. In fact, that was mass migration of men, women and their children from different parts of the Achaemenid Empire, organised in the context of military operations in and around the Greek world. Those migrations should be placed entirely in a Persian cultural, economic, political and administrative context. The deported people should be perceived as a part of the Persian economic system. They were dependent workers resettled all over the empire, being part of the estates of the ruler and of his close circles. ${ }^{6}$ An interesting example in this respect can be seen in the letters of the late $5^{\text {th }}$ century BC satrap of Egypt Arsames who wrote letters to the manager of his estates in Egypt in Aramaic, and precisely in those letters one can see the Persian word garda corresponding to the Elamite word kurtaš. ${ }^{7}$

comments. A large part of that evidence has also been commended by Briant, 2002: 505-506.

${ }^{3}$ Aperghis, 2000: 127-144.

${ }^{4}$ On these early Greek-Persian contacts, see: Функ, 1990: 2-23.

${ }^{5}$ Demand, 1988: 416-423; Demand, 1990: 34-44

${ }^{6}$ On the non-slave forms of dependence in the ancient East, see: Дандамаев, 1984: $5-25$.

${ }^{7}$ This Persian word is attested in texts in Akkadian in the form gardu, as well as gardupatu - leader of gardu. 
That corresponded to the word in the Persian language. They were dependent workers in Persian royal estates and in that belonging to the Persian elite. Many documents from the Persepolis terrace mention those dependent people. The documents refer most frequently to monthly rations in kind or in silver for the workers and for high-ranking state officials. That information originates from more than 2,000 tablets published by Richard Hallock ${ }^{8}$, referred to as Persepolis fortification tablets. We learn from the Persepolis tablets about rations paid in the form of farm produce and silver to builders working on the big construction sites, predominantly in Persepolis. These tablets were published by George Cameron. ${ }^{9}$ All these documents are dated to the rule of the Great Kings Darius I, Xerxes and Artaxerxes I. The tablets from the Persepolis fortification are dated to 509-494 BC, those from the treasure house - to $492-458 \mathrm{BC}$. The social and economic status of the people in the Persian economic system, mentioned in these texts, is very unclear. Many speculations exist: from comparisons of the kurtaš workers with Greek regalia denoting slaves, e.g., oiketes and laoi, to the most common Greek word for slaves: douloi. In my opinion, the cultural, administrative and economic context of these Persian practices of mass deportations of workers should be sought above all in the old Mesopotamian world on account of the numerous instances there of deportations of "prisoners of war."

They were exploited on major state construction sites, in irrigation construction and as workers in royal or private farms. After they were taken in captivity, they became part of the complicated Mesopotamian system of social and economic relations. They were dependent those people were exploited on major state construction sites, in irrigation construction and as workers in royal or private farms. After they were taken in captivity, they became part of the complicated Mesopotamian system of social and economic relations. They were dependent people and became part of the intricate social system. A formula phrase for people deported during war is used in some of these texts. The formula of expression is similar and is actually aimed at showing a phrase referring to people in captivity, which originated from ancient Mesopotamia and is attested in Akkadian as niše seher rabi zikar u sinniš - "people, big and small, men and women." Deported people in captivity - men, women and children - are also seen on reliefs of the Assyrian kings. ${ }^{10}$

Unlike the Mesopotamian communities, which were predominantly urban, Persian society at the time of the Achaemenids was mostly tribal and not well familiar with urban culture. The Persians lived, in the words of Aristotle, katha ethne. That was the main reason for the serious differences in the social systems of ancient Mesopotamia

\footnotetext{
${ }^{8}$ Hallock, 1969; Hallock, 1978: 109-136.

${ }^{9}$ Cameron, 1948; Cameron, 1958: 161-176; Cameron, 1965: 167-192.

${ }^{10}$ Oded, 1979: 23; Pritchard, 1954: nos. 10, 358-359, 373.
} 
and Achaemenid Persia. The kurtaš (garda workers), gathered from different parts of the empire, were attached to their settlements for life. Their progeny also inherited their social status.

There are numerous examples in Mesopotamian societies from the time of the Sargonides, as well as in subsequent times, e.g., during the Ur III period, of rations given to captives working in farms or engaged in construction, and those workers were described as dependent people: "prisoners of war". Many of them were referred to as "booty" in royal inscriptions and were part of the state property. ${ }^{11}$ They had different fate. Many of them were offered as a gift to places of worship or to high-ranking state officials. They received rations of wheat, flour or beer, just like the kurtaš workers in the Achaemenid royal estates.

The rations distributed in ancient Mesopotamia were comparable to those dispensed from the royal warehouses in Achaemenid Persis and Elam. ${ }^{12}$ The rations were strictly differentiated according to age and gender in Mesopotamia and in Achaemenid Persia.

During the New Babylonian period, foreigners were also involved in the empire's social, economic and even administrative system. Those were the hatru communities - groups of foreigners living separately in Babylonia, who were even recognised by the Achaemenid authorities. They lived in settlements of their own and had their peculiar autonomy, being ruled by their own structures. They preserved their customs and they even sued each other. ${ }^{13}$ That situation was comparable to the one in the Persepolis fortification tablets, where compact groups of workers lived in separate settlements and engaged in agriculture and stockbreeding.

The earliest information about mass deportations carried out by the Achaemenid rulers is found in Histories by Herodotus. In the contest of a military operation, the Median general Mazares "enslaved" the inhabitants of Priene in Ionia. According to the "Father of History" he enslaved $(\dot{\varepsilon} \xi \alpha v \delta \rho \alpha \pi \circ \delta i \zeta \omega)$ citizens of Priene (Hdt. 1, 161). That event is dated ca. $545 \mathrm{BC}$ and it was the earliest for the practices of the mass deportations of kurtaš (garda) workers in the Achaemenid Empire. ${ }^{14}$ That evidence confirms that even under Cyrus the Great there were farms of the king (and of the nobility), which used the labour of dependent people. Cyrus also ordered the Median Mazares to "enslave" those who attacked Sardis together with the Lydians (Hdt. 1. 156). "Enslaving" should again be understood as mass migration of working population.

\footnotetext{
${ }^{11}$ Gelb, 1973: 74-75.

12 Gelb, 1965: 230-243.

${ }^{13}$ Moukarzel, 2014: 139-143; Briant, 2002: 505.

${ }^{14}$ On Priene and the assumed metoikesis, see Demand, 1986: 35-44.
} 
The next evidence is from Persica by Ctesias of Cnidus. According to his narrative in the context of the conquering of Egypt by the Persian Great King Cambyses in 525 BC he led 6,000 Egyptians to Susa, as well as the captive Egyptian pharaoh (Ctes. Pers. Fr. 13, 10). Those workers were engaged above all in the royal constructions. Some facts are mentioned by Diodorus Siculus in his first book and probably followed the narrative of the physician from Cnidus (Diod. 1, $46,4) .{ }^{15}$ I would like to link that information with the words in one of the inscriptions of the Great Persian Kings, e.g., the inscription of King Darius from Susa, referring to materials brought from different parts of the empire. That inscription ( $D S f, 52-53)$ mentions Egyptian workers (from the Mudrâyâ satrapy in Egypt). The Egyptians are also frequently mentioned in the Persepolis archives. ${ }^{16}$

Again Ctesias of Cnidus refers to events prior to the Scythian campaign of King Darius I in another passage of his Persica (Ctes. Pers. Fr. 16, 20). According to that information, the satrap of Cappadocia (Old Pers. Katpatuka) Ariaramnes organised a sea expedition against the Scythians in Europe with 30 ships with 50 oars (penteconteras) and he took Scythians as prisoners of war - 'men and women prisoners of

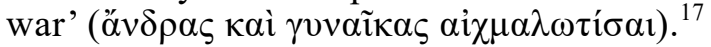

Again Herodotus informs that there were many migrants from other parts of the empire in the islands in the Red Sea. They are mentioned in that case as being mixed with the indigenous communities as Sagartians, Sarangians and other tribes. That narrative by Herodotus about dependent tribes and deported people is from Herodotus' list with the Persian provinces, and the tax that he informs that those people paid was 600 talents (Hdt. 3, 93) ${ }^{18}$ The issue of the status of those foreigners resettled on the islands is important in this case. If they paid equal taxes with the local free population, they were not part of the kurtaš working population in that satrapy, and were hence free people. According to another evidence of the "Father of History," those people were migrants and wore the same clothes as the Mydians (Hdt. 7,80 ). We learn from the same passage that they participated with their contingent in the army of Xerxes. Quintus Curtius Rufus informs that Euboeans resettled from Susiana sent their contingent to the army of Darius III (Curt. 5, 1,2). They, too, were probably settlers with dependent workers status. That was the second evidence, moreover from the Greek historiographic tradition, according to which dependent people with kurtaš status sent contingents to the Persian armies and were hence subject to obligatory conscription. ${ }^{19}$ In that passage Herodotus

${ }^{15}$ In this passage Diodorus mixes information by Herodotus and by Ctesias of Cnidus (Ctes. Pers. Fr. 13, 10).

${ }^{16}$ Henkelman, 2017: 273-363.

${ }^{17}$ Ctesias uses here a formula phrase of Near Eastern origin, which occurs in New Assyrian and in other later Mesopotamian texts.

${ }^{18}$ On the satrapy, see: Potts, 2013a.

${ }^{19}$ See exhaustive information about those events in Briant, 2002: 759. 
gives a term denoting those people: "...the so-called settlers" in which he uses the word $\dot{\alpha} v \alpha \sigma \pi \alpha \sigma \tau o \dot{~-~ " c o e r c i v e l y ~ r e s e t t l e d ~ p e o p l e . " ~ H e ~ a c t u a l-~}$ ly explains with the phrase "so-called" a Persian linguistic realia to denote such people, which unfortunately remains unknown to us. Did Herodotus actually try to tell us about the social status of those people - different from that of dependent workers, about whom, incidentally, we do not know whether they paid taxes, as they received rations from the royal warehouses? In passage 7,80 , in describing the Persian army led by Xerxes, the "Father of History" denoted those recruited people as $\dot{\alpha} v \alpha \sigma \pi \alpha \sigma \tau$ oí. Herodotus uses the word $\alpha v \alpha \sigma \pi \alpha \sigma \tau o v \varsigma$ also for the resettled citizens of Barka (Hdt. 4, 204), as well as for the resettled Paeonians along the Strymon River in Anatolia (Hdt. 5, 12). ${ }^{20}$ The Persepolis fortification tablets attest the representatives of the Thracian-Phrygian community as the most numerous kurtaš population, above all from ancient Anatolia. ${ }^{21}$

In another passage by the Halicarnassian, this word $-\dot{\alpha} v \alpha \sigma \pi \alpha \sigma-$

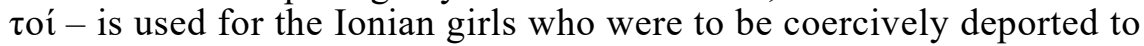
Bactria, if the Ionians did not surrender at the end of the Ionian Revolt (Hdt. 6, 9). Again in a similar context, Herodotus informs about the Ionian boys who were castrated and about those forcibly led to the Great King Darius I (Hdt. 6, 32). ${ }^{22}$ That happened after the second conquest of Ionia following the failed uprising. ${ }^{23}$ That term was also used by Flavius Arrianus in his work on the campaigns of Alexander the Great. In those passages he associated the word with the coercively deported Carians that the troops of the King of the Macedonians found there. He denoted them as Kã $\rho \varepsilon \varsigma \dot{\alpha} v \alpha \sigma \pi \alpha \sigma \tau o$ (Arr. Anab. 3, 8, 5; 3, 11, $5 ; 3,13,1)$. As can be seen, the word was used in those times above all with respect to coercively deported people during some military conflict, those deportations being in the context of the Persian military activities in the Mediterranean.

The next evidence also comes from Herodotus' text and concerns ancient Thrace. In the context of his Thracian campaign ca. 510 $\mathrm{BC}$, the Persian general Megabazus defeated some of the Paeonian tribes and led to Persia parts of the Paeonian population: men, women and children. They were resettled in a village and the territories

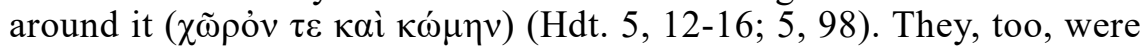
captives in the context of a military operation of the Persian army in Southeastern Europe, being prisoners of war and having the status of kurtaš workers in a Persian province like Phrygia. In that sense, those migrants were part of a estate of the Great King or of a high-ranking Persian official. Although that narrative by Herodotus is anecdotal,

${ }^{20}$ On the Paeonians, see Delev, 2000: 49-53; Делев, 2014: 399-408.

${ }^{21}$ Henkelman, Stolper, 2009: 271-329.

22 See Lenfant, 2012: 257-297 on the eunuchs in the Achaemenid Empire and the Greek biased perspective on that reality, according to the narratives of Ctesias of Cnidus.

${ }^{23}$ Powell, 1938: 23, s.v. àv $\alpha \sigma \pi \alpha \sigma \tau o \varsigma$. 
above all in the part about the "industrious Paeonian woman" and her two brothers, it may be judged that there were real historical events behind that narrative, all the more that the Halicarnassian traces in 5, 98 the story about the return to Thrace of a part of those migrants, after they had spent more than 15 years in Anatolia as kurtaš workers. The duration of that dependence of theirs can also be examined here. It may be concluded from Herodotus' narrative that their dependence lasted for life, and their children inherited the same social status.

Again Herodotus informs about the workers who dug the canal across Mount Athos in 483 BC. In my opinion, those indebted people from the surrounding Greek and Thracian population had the same social status: of dependent kurtaš workers. This is clearly seen from the system of supplying them with food rations for their work. ${ }^{24}$ Even a market was arranged for them, where they could exchange products. The Phoenicians coped best with the work assigned to them (Hdt. 7, 22-23).

Another passage in Herodotus informs about mass deportation of inhabitants of the Greek polis Barca (Hdt. 4, 165-167; 200-204). Citizens of Barca were enslaved, to use the expression of the Halicarnassian (B $\alpha \rho \kappa \alpha i ́ \omega v$ oi Пદ́ $\rho \sigma \alpha \imath \dot{\alpha} v \delta \rho \alpha \pi \circ \delta ı \sigma \alpha ́ \mu \varepsilon v o \imath)(H d t .4,203)$. After those events, the hostages from Barca were sent first to Egypt and then to the Great King in Persia. According to Herodotus, Darius I, on his own orders, resettled them in a settlement in Bactria (similar to the Paeonians deported again by Darius to a village and its adjacent lands). They gave the name Barca to the village and lived there at least until Herodotus' time. ${ }^{25}$ A similar situation is found in documents from the Persepolis fortification tablets. According to a document, King Darius personally ordered a certain number of sheep from the royal estate to be given to Irtašduna who was connected to his family ( $P F$ 1128; 1184). This is again an order issued by the king personally, or at least this is expressly fixed in the document. ${ }^{26}$ The resettled population gave the name to the new settlement: Barca. At the time of Herodotus they still inhabited the same place in the lands of Bactria. For more than 60 years those people and their children were most probably kurtaš workers in the royal estate (on the personal order of Darius I), which was part of the royal economy.

At the end of the Ionian rebellion, the Persians conquered Miletus and deported the survivors - mostly women and children. They were resettled in the area of Susa and the Great King Darius I issued again the order for their deportation. Those people were resettled in a place specifically referred to by Herodotus as "polis" and localised at the Tigris Delta (Hdt. 6, 18-22). ${ }^{27}$ Two other passages by Herodotus clearly

\footnotetext{
${ }^{24}$ On the royal warehouses in Persis and Elam, see Aperghis, 1999: 152-193.

${ }^{25}$ Briant, 2002: 505.

${ }^{26}$ Cameron, 1942: 214-218.

${ }^{27}$ Andreas, 1894: 1877-1880.
} 
refer to the Persian appeals for the defeated Ionians to be enslaved at the end of their rebellion. According to these two phrases (Hdt. 6, 9-10; $6,32)$, they mention acts with which they were threatened and then the real actions are noted. The phrase addressed by the Persians to the Ionians reads as follows: it is reported that the Ionians "will be enslaved, that their sons will be castrated and their girls - abducted to Bactria, and that their country will be given to others" (Hdt. 6, 9-10). This is actually a threat of mass deportation, but sounds as a formula phrase and is repeated by Herodotus in 6, 32, where those events are already claimed to have taken place. ${ }^{28}$

The Ionians (Yauna) or the Greeks are generally well attested in the Persepolis archives (fortification and from the treasury). Only one published tablet written in Greek is known, which mentions wine and the Persian linguistic loan marrišs, introduced into Greek, i.e. the tablet Fort. 1771. Tablet PF 1224 mentions mothers of Greek origin, the socalled post partum, who received wine rations for having given birth to their children recently. Greeks and Lycians were engaged in agriculture and stockbreeding, according to the texts from the Persepolis fortification. It cannot be stated with certainty in the context of what events those people landed in Persis and Elam. Diodorus claims that they were resettled to those regions, near the Araxes River under the "previous Persian kings." In the historian's words, they numbered 800 (Diod. 17, 69, 2-3). ${ }^{29}$ The presence of Greeks in the regions of Persis and Elam is attested not only by graffiti in Greek, they are also mentioned in the texts from Persepolis ( $P F$ 2072), e.g., a person is attested in a text, being denoted with the ethnonym Yauna, which is used as patronymic. He was probably a Greek appointed to an administrative post and responsible for the granaries (PF 1942; 1965). In 499-498 BC he was part of a structure under the supervision of two high-ranking Persian officials: Parnaka and Ziššawiš. ${ }^{30}$ One of the Persian royal inscriptions from Susa refers to Greek craftsmen (DSf, 29, 42).

Again at the time of the Great King Darius I, his generals Datis and Artaphernes, who commanded the military operation at sea against Mainland Greece, captured citizens of the Greek polis Eretria in 490 BC. They led the captives again to Susa, the administrative capital of the Achaemenid Empire. Again on the orders of King Darius, they were resettled to his estate in a region called Kisia, in a place called Arderika. That place was located near Susa. They extracted three things from wells: asphalt, salt and oil. According to the evidence of

\footnotetext{
${ }^{28}$ A similar phrase is also found in the Old Testament library, in Judith. The phrase pronounced by the New Babylonian ruler Nebuchadnezzar concerns the Jews in Judaea and reads: "I will take captive all those who are left alive and carry them off to the ends of the Earth" (Judith, 2, 9) (Briant 2002: 505).

${ }^{29}$ This story was narrated also by Quintus Curtius Rufus $(5,5,5-24)$, as well as by Justin (11, 14, 11-12), being absent in Plutarch and Flavius Arrianus.

${ }^{30}$ Briant, 2002: 506.
} 
Herodotus, those people inhabited the same place during his time as well (Hdt. 6, 98-101; 119-120). ${ }^{31}$ They, too, were resettled on the orders of the Great King, after they were led to Susa. The estate where they worked as kurtaš workers was part of the system of royal estates in Persis and Elam, mentioned above all in the Persepolis fortification tablets. Here I would like to stress the specific claim of Herodotus that they had been resettled on Darius' personal will in his estate. In most cases the hostages were taken to Susa, the administrative capital of the empire, and from there they were distributed in various parts of the empire, in the estates of the Great King and of his close circles.

On his part, centuries after those events, Diodorus Siculus mentions mass deportation of Boeotians to the land of the Kelonians (kelonas), where Alexander the Great gave orders for his army to rest during the Eastern campaigns. Those people had been resettled there at the time of Xerxes and until that time they observed their customs and rituals, according to the Sicilian historian. They spoke their native language, as well as the language of the local people (Diod. 17, 110, 4-5). The Sicilian historian also refers to "Karian villages" close to Susa (Diod. 17, 110, 3). Diodorus mentions a Carian village close to Babylon in $19,12,1$. That was a community composed either of kurtaš, or of a hatru community. Those events are dated to the winter of 318/17 BC. Quintus Curtius Rufus writes about Greeks who were captives in the Persepolis area. They were tortured and - in the words of Rufus - they were branded with "barbarian letters" (Q. C. Rufus, 5, 5, 5-24). That practice was reminiscent of the branding of garda (kurtaš) workers on the orders of Egypt's satrap Arsames at the end of the $5^{\text {th }}$ century BC. He mentions that order in a letter to the manager of his estate in the cited Persian satrapy.

From the Persepolis fortification archive there are parallels for self-organisation of resettled kurtaš workers, who had preserved their traditions, language and culture, living in homogeneous groups in Persis and Elam. This leads to the conclusion that - as is observed in the Persepolis tablets - in most cases ethnic belonging was reported for ethnically compact groups of kurtaš workers engaged in concrete activities.

Strabo and Quintus Curtius Rufus also reported about the migration of the Branchiades, who ceded to the Persians the wealth of the sanctuary in Didyma. Many years later, Alexander the Great destroyed their settlements in Sogdia and Bactria (Strabo 11, 11, 4; Q. Curt. 7, 5, 28-35).

Paulus Orosius mentions Judaeans who were deported from Egypt during the reign of the Great Persian King Artaxerxes III Ochus (359-338 BC). They were resettled in Hyrcania, close to the Caspian Sea (Paul. Oros. Ad Pag. 3,7,6-8). Orosius borrowed that narrative from the chronicle of Eusebius Hieronymus (Hieron. 1658m).

${ }^{31}$ Grosso, 1958: 350-375. 
Chronicle No 9 from the time of the reign of Artaxerxes III also informs that inhabitants of Sidon were deported to Babylon and Susa as prisoners of war - ["men"] and women. ${ }^{32}$ There is a lacoon in the text, but I think that it can be filled with "[men] and women, captives from Sidon." The document is dated to the $14^{\text {th }}$ year of the rule of Artaxerxes III, or of Umasu, that Persian ruler being attested in the Akkadian sources. That situation with the sources is comparable to the Phoenicians mentioned by Herodotus, who took part in the digging of the canal across Mount Athos (Hdt. 7, 23).

6 UD XVI ${ }^{\mathrm{kám}} \mathrm{SAL}^{\mathrm{mes̆}} \mathrm{SIG} \mathrm{mes̆} h u b t u(\mathrm{sar})^{t \grave{u}}$ šá kur $S i-d a-n u$

According to our calendar, the document is dated to October 345 BC. It was at that time that Artaxerxes III conducted an operation against the insurgent Phoenician cities and destroyed Sidon, taking hostages - probably mentioned in the cited Late Babylonian Chronicle No 9. It was part of a business document and was written on one side of a clay tablet. ${ }^{33}$

Diodorus Siculus also narrates about those events. In 349 BC, the Phoenician cities rallied around Tripolis rebelled against Persia. They were supported by the already liberated Egypt. Sidon with its King Tennes was at the head of the rebellion. The insurgents destroyed the royal paradeisos, located in the area around Sidon. Besides, they burned down the nearby village, as well as the storage facilities for food intended for the Persian cavalry, and they killed the king's officials. The Sidonians built battleships and accumulated food and weapons. In addition to the volunteers, they hired mercenaries as well. They requested aid from Egypt in 346 BC. The Egyptian Pharaoh Nectanebo sent 4,000 Greek mercenaries under the command of Mentor from Rhodes to help Sidon. With the help of all these forces, the Sidonian King Tennes succeeded in defeating twice the Persian armies sent against him, under the command of satraps. These successes of the Phoenicians led to proliferation of the rebellion to Cilicia, Judaea and Cyprus. Hence Artaxerxes III personally assumed the command. In $345 \mathrm{BC}$ he gathered an army and set off to Phoenicia. According to Diodorus, his army numbered 300 thousand warriors. However, the Sidonian king Tennes betrayed the city and abandoned it. Artaxerxes punished the city severely. According to the Sicilian historian, 40 thousand Sidonians perished (Diod. 16, 43-45). In 344 BC, the remaining Phoenician cities ended their resistance. ${ }^{34}$ In this connection it should be noted that Diodorus $(16,45,1-6)$ did not write about captured Sidonians who were taken to Babylon and Susa, but about 40 thousand dead

\footnotetext{
${ }^{32} \mathrm{ABC}=$ Grayson, 1975: 114, line 6.

${ }^{33}$ See: Strassmaier, 1889: 281-283; Barag, 1966: 8, Note 7; Smith, 1975: 148.

34 Дандамаев, 1985: 250-251.
} 
from Sidon: whole families and their servants who perished in the flames of fires that they themselves caused. ${ }^{35}$

The social status of the resettled people was of kurtaš workers in the royal estates in Persia and in other parts of the empire. The data suggest predominantly migrations of Greeks, although evidence is found for Paeonians and Phoenicians, as well as Carians and Scythians. These data complement the picture seen in the Persepolis archives and indicate migrations of foreigners outside Persis and Elam. The data from Persepolis give information on the structure of the royal estates precisely in those two Persian provinces, but the distant echo of those Persian practices reveals also migrations in other parts of the vast empire. This fragmentary information, of which the Greeks were not very well aware, reveals a broader picture of the ancient Persian practices of recruiting dependent workers. They reveal also occupations that were not attested in the Persepolis archives. It is necessary to add to this evidence also the letters of Arsames, the satrap of Egypt, at the end of the $5^{\text {th }}$ century BC, to the managers of his estates in Egypt. These letters add another touch to the estates belonging to the Persian nobility in the different provinces. These letters are important precisely for the better understanding of the functioning of the royal economy at imperial level, as well as for the better understanding of the relations between central power and the local power structures. ${ }^{36}$

Did Herodotus use the word for coercively resettled people $\dot{\alpha} v \alpha \sigma \pi \alpha \sigma \tau o \dot{i}$ - for the mass deportations carried out by the Persian authorities, and whether, when referring to "enslaved" people he did not mean different events? Thus, for example, in 6,101 he refers to the Eritreans as "enslaved" people, but explains the situation in 6, 119 with the claim that the hostages were taken to Susa and resettled there as kurtaš workers.

\section{BIBLIOGRAPHY}

Andreas, F. C. (1894): “Ampe”, RE, I, 1894, col. 1877-1880.

Aperghis G.G. (1999): "Storehouses and Systems at Persepolis: Evidence from the Persepolis Fortification Tablets", Journal of the Economic and Social History of the Orient, Vol. 42, No. 2, 1999, pp. 152-193.

Aperghis G.G. (2000): "War captives and economic exploitation. Evidence from Persepolis Fortification Tablets", in: J.Andreau, P. Briant, R. Descat (ed.) La guerre dans les economies antiques, Saint Bertrand de Comminges, 2000, pp. 127-144.

${ }^{35}$ Sidon was hardly damaged as much as Diodorus claims, because according to Flavius Arrianus and Quintus Curtius Rufus, that Phoenician city was rich and flourishing at the time of Alexander the Great (Arr. Anab. 2, 20; Curt. 4, 1, 15).

${ }^{36}$ Dandamayev, 1963: 147-154. 
Barag, D. (1966): Effects of the Tennes Rebelion on Palestine, Bulletin of the American Schools of Oriental Research, 183, 1966, pp. 6-12.

Briant, P. (2002): From Cyrus to Alexander. A History of the Persian Empire, Eisenbrauns, 2002.

Cameron, G.G. (1942): Darius' daughter and the Persian Inscriptions, Journal of Near Eastern Sstudies, 1942, vol. 1, fasc. 2, pp. 214-218.

Cameron, G.G. (1948): Persepolis Treasury Tablets (The University of Chicago, Oriental Institute Publications 65), Chicago, University of Chicago Press, 1948.

Cameron, G.G. (1958): "Persepolis Treasury Tablets Old and New", Journal of Near Eastern Studies, 17, 1958, pp. 161-176.

Cameron, G.G. (1965): "New Tablets from the Persepolis Treasury", Journal of Near Eastern Sstudies, 24, 1965, pp. 167-192.

Dandamayev, M. (1963): Foreign Slaves on the Estates of the Achaemenid Kings and their Nobles, in: Tpуды XXV международный конгресс востоковедов, Т. 2, Москва, 1963, pp. 147-154.

Delev, P. (2000): "The Deportation of the Paeonians in Herodotus", Thracia 13, Studia in memoriam Velizari Velkov, Serdicae, 2000, pp. 49-53.

Demand. N. (1990): Urban Relocation in Archaic and Classical Greece: Flight and Consolidation, University of Oklahoma Press, 1990.

Demand, N. (1988): "Herodotus and Metoikesis in the Persian Wars", The American Journal of Philology, 109, No. 3, 1988, pp. 416-423.

Demand, N. (1986): “The Relocation of Priene, Reconsidered", Phoenix, Vol. 40, No. 1, 1986, pp. 35-44.

Grayson, A.K. (1975): Assyrian and Babylonian Chronicles, New York, 1975.

Hallock, R.T. (1969): Persepolis Fortification Tablets, Chicago, University of Chicago Press, 1969.

Hallock R.T. (1978): "Selected Fortification Texts", Cahiers de la Delegation Archeologique Francaise en Iran, 8, 1978, pp. 109-136.

Henkelman. W. (2017): "Egyptians in the Persepolis Archives", in: M. Wasmuth. Ägypto-persische Herrscher und Herrschaftspräsentation in der Achämenidenzeit, Stuttgart, Franz Steiner Verlag, 2017, pp. 273-363.

Henkelman, W. F. M.; M W. Stolper. (2009): "Ethnic Identity and Ethnic Labeling at Persepolis: the Case of the Skudrians" in: P. Briant, M. Chauveau. Organisation des pouvoirs et contacts culturels dans les pays de l'empire Achemeneide (Persica 14), Paris, De Boccard, 2009, pp. 271-329.

Hirsch, St.(1992): "The Deportation of the Paeonians: Persian Imperial Strategies and the Experiences of the Thracian Deportees", in: VI Syposium Internazionale di Tracologia. I Traci nel Mediterraneo, Roma, 1992, pp. 230-239.

Gelb, I. J. (1973): "Prisoners of War in Early Mesopotamia", Journal of Near Eastern Studies, 1/2, 32, 1973, pp. 70-98.

Gelb. I. J. (1965): “The Ancient Mesopotamian Ration System”, Journal of Near Eastern Studies, Vol. 24, No. 3, Erich F. Schmidt Memorial Issue, 1965, pp. 230243.

Grayson, A. K. (1975): Assyrian and Babylonian Chronicles, New York, Locust Valley, 1975.

Grosso F. (1958): "Gli Eretriesi deportati in Persia", Revista di filologia e di istruzione classica 86, 4, 1958, pp. 350-375.

Lenfant, D. (2012): "Ctesias and his Eunuchs: A Challenge for Modern Historians", Histos, 6, 2012, pp. 257-297.

Moukarzel, K. (2014): "Some Observations about 'Foreigners' in Babylonia during the VI Century BC", in: M. Geller (ed.). Melammu: The Ancient World in an Age of Globalization, Berlin, Edition Open Access, 2014, pp. 129-155. 
Oded, B. (1979): Mass Deportations and Deportees in the Neo-Assyrian Empire, Wiesbaden, 1979.

Potts, D. T. (2013): "The Islands of the XIV-th Satrapy", in: R. Oetjen, F. Ryan (eds.). Seleukeia: Studies in Seleucid History, Archaeology, and Numismatics in Honour of Getzel Cohen, Stuttgart, Steiner Verlag, 2013.

Potts, D.T. (2013): "Mesopotamian and Persian Migrations", in: The Encyclopedia of Global Migration, Blackwell Publishing, 2013, pp. 1-6.

Powell, J. E. (1938): A Lexicon to Herodotus, Cambridge, Cambridge University Press, 1938.

Shahbazi, S., E. Kettenhofen, J. R. Perry, (2016): "Deportations", in: Encyclopaedia Iranica, Vol. VII, Fasc. 3, 1994, pp. 297-312, At www.iranica.com/articles/deportations, accessed Nov. 25, 2016.

Smith, S. (1924): Babylonian Historical Texts, London, 1924.

Strassmaier, J. N. (1889): "Einige kleine babylonischen Keilschrift - texte aus dem Britische Museum", in Actes du 8-e Congres International des Orientalistes, Leiden, Brill, 1889, pp. 281-283.

Дандамаев, М. (1985): Политическая история Ахеменидской державы, Москва, 1985.

Дандамаев М. (1984): “Нерабские формы зависимости в древней передний Азии (к постановке вопроса)”, В: М. Дандамаев (ред.) Проблемы соииальных отношений и форм зависимости на древнем Востоке, Москва, 1984, pp. 5-25.

Делев, П. (2014): История на племената в Югозападна Тракия през І хил. пр. Хр., София, Университетско издателство, 2014, pp. 399-408.

Дьяконов, И. М. (1952): “К вопросу о судьбе пленных в Ассирии и Урарту”, в: Вестник Древней Истории, 2, 1952, pp. 90-100.

Функ, Б. (1990): “Ранние связи греков с державой Ахеменидов в свете древнеперсидских и античных источников”, Вестник Древней Истории, 2, 1990, pp. 2-23. 
